\section{ECONOMICS}

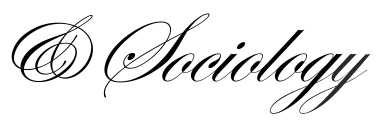

\title{
DETERMINING FACTORS IN BECOMING A SUSTAINABLE SMART CITY: AN EMPIRICAL STUDY IN EUROPE
}

\author{
María Teresa Nevado Gil \\ University of Extremadura, \\ Facultad de Empresas, Finanzas y \\ Turismo, Cáceres, Spain \\ E-mail:tnevado@unex.es \\ ORCID 0000-0002-4924-0908
}

\section{Luísa Carvalho}

Institute Polytechnic of Setúbal,

School of Business and

Administration, Setúbal \&

CEFAGE-University of Évora,

Portugal

E-mail:

luisa.c.carvalbo@,esce.ips.pt

ORCID 0000-0002-9804-7813

\section{Inna Paiva}

Instituto Universitário de Lisboa

(ISCTE-IUL), Business Research

Unit (BRU-IUL), Lisboa,

Portugal

Email: InnaPaiva@,iscte-iul.pt

ORCID 0000-0002-9980-7503

Received: August, 2019

1st Revision: October, 2019

Accepted: February, 2020

DOI: $10.14254 / 2071$ -

789X.2020/13-1/2

JEL Classification: H0, H70, O10, Q56
ABSTRACT. This paper aims firstly to identify differences and similarities between cities according to the activities which are necessary to become a smart city and secondly to identify relevant factors that could influence positions in the smart cities ranking. To achieve these goals, this study uses a quantitative analysis applied to 73 European cities to identify the factors that influence differences between smart cities. The results suggest the formation of clusters around European smart cities and also that cities located geographically in the west of Europe and with governance by women present higher levels in the European Smart Cities rankings.

Keywords: smart cities, Europe, sustainability, factors 


\section{Introduction}

Cities around the world are registering rapid growth, which implies improvements in the quality of life and improvements in the efficiency of city administration activities (Karyy \& Knjazevska, 2008). In this context, studies on smart cities around the world have become more popular in recent years (Abdala et al., 2014). National and international organizations have developed studies in order to define smart cities and to create and apply relevant indicators to measure them. Several studies suggest that these cities reveal higher values in the indicators for measuring and classifying smart cities.

The importance of the relationship between sustainable smart cities and the factors fpr their development in the business world has increased in recent years. Regional development is based on the dynamics of creative and intelligent territories, where different partners intervene in a collaborative way, creating conditions that contribute to an improvement in the state of living, the economy, mobility, job creation, regional competitiveness and other benefits. Intelligent cities work in networks to promote political and social efficiency, which allows social, cultural and urban development in the territory (Carvalho, 2017) and also make use of digital tools and ICT (Lee et al., 2013; Walravens, 2012). Smart cities generate various business opportunities and possibilities for collaboration between the public and private sectors. All stakeholders can contribute by creating a network with public organizations, institutions, governments, universities, experts, research centres, etc. A smart city is linked to some components which are related to a set of aspects of urban life (Lombardi et al, 2012):

- smart economy: industry

- smart people: education

- smart governance: e-democracy

- smart mobility: logistics and infrastructures

- smart environment: efficiency and sustainability

- smart living: security and quality

In these times, cities are urban spaces that face challenges and opportunities (Washburn et al., 2010; Carvalho, 2017). According to UNEP (2011), cities account for 50\% of the world's population. They contribute to $60 \%-80 \%$ of the energy consumed, $75 \%$ of the carbon emitted and give rise to inequalities and social exclusion. The UNO (2012) forecasts a population growth from 7 to 9 billion by 2040, especially in developing countries. However, cities are regional spaces that promote innovation, knowledge and creativity. The biggest cities in the world will manage 60\% of the world's GDP in 2025 (McKinsey, 2011). Consequently, it is imperative to develop and adjust urban models attending to demographic, economic, social and environmental constraints (Hammer et al., 2011; Turcu, 2013).

Over recent decades, national and international organizations have produced studies focusing on the definition, creation and use of indicators for the measurement and benchmarking of smart cities. Moreover, several approaches, aims and methodologies can be found to diagnose and rank smart cities. Most of the literature reports that these cities reveal high values in the indicators created to measure and rank intelligent cities (Giffinger et al., 2007). In this context, this study aims to identify which factors influence the development of sustainable smart cities. This study is important because empirical academic studies on smart cities are still underexplored and have not addressed this perspective.

The objective of this study is to analyse the factors that influence the development of sustainable smart cities. More specifically, we present descriptive and stylised evidence on factors that evidence differences across smart cities in Europe, using multivariate analysis. After that, we discuss which clusters are likely to persist given the complementarities among different factors. The empirical study investigates factors that influence the development of sustainable 
smart cities in Europe. We conducted our empirical study in European smart cities because the European Union highlights the importance of smart cities to the economy and to sustainable development. The EU's 2020 objectives include developing and redeveloping smart, sustainable and inclusive cities and communities in Europe (European Union, 2014).

We used the data from the IESE Cities in Motion Index 2017 (CIMI) developed by the IESE Business School (Berrone \& Ricart, 2017). The CIMI has developed an empirically validated conceptual model which assesses cities in 10 key dimensions: the economy, human capital, technology, the environment, international outreach, social cohesion, mobility and transportation, governance, urban planning and public management. All the indicators are linked to a strategic aim that leads to a novel form of local economic development: the creation of a global city and the promotion of entrepreneurial spirit and innovation, among others. Our final sample is composed by 73 European cities ranked by the IESE Cities in Motion Index 2017.

We focus on the cluster analyses used by previous empirical studies such as Mar and Serrano (2001), Pérez (2001), Pardo and Ruíz (2005), Navarro et al. (2010) and Nevado and Gallardo (2016), applying the most appropriate method to obtain more interpretable information. Our results demonstrate that there are robust institutional clusters around European smart cities. We discuss whether these clusters are likely to persist given the complementarities among different factors. Analysis of the factors that influence the development of sustainable smart cities is in a relatively early phase of development and our study makes several contributions to the literature addressing regional development and smart cities.

This study makes several contributions to the literature. Principally, it contributes to and understanding of the factors that influence the development of sustainable smart cities in the European context.

The remainder of the paper is organized as follows. The next section reviews the previous literature on and regional development of smart cities and presents our hypotheses. In the third section, we describe the data and research method. The fourth section presents the results of the descriptive analysis and cluster analysis. The work concludes by outlining the main aspects of current problems and future challenges of smart cities.

\section{Literature review}

\subsection{Smart cities}

As far as the definition for "smart city" is concerned, there is no universally accepted definition and some authors have registered a "lack of definitorial precision" (Hollands, 2008). Cities use this discrepancy and try to self-define as smart cities (Hollands, 2008; Caragliu et al., 2011; Tranos and Gertner, 2012). Early research suggests that a smart city is "the urban center of the future, made safe, secure environmentally green, and efficient because all structures whether for power, water, transportation, etc. are designed, built and maintained making use of advanced and integrated materials, sensors, electronics, and networks which are interfaced with computerized systems" (Hall, 2000, p. 1).

Komninos (2006) related the definition of the smart city to knowledge and learning, stressing the potential for knowledge creation using digital infrastructures. Smart cities are "Territories with high capacity for learning and innovation, which are built on the creativity of their population, their institutions of knowledge creation, and their digital infrastructures for communication and knowledge management" (Komninos, 2006, p. 6). Giffinger et al. (2007, p. 11) related smart cities to six characteristics, supported on the smart combinations of 
endowments (a smart economy, smart mobility, smart environment, smart people, smart living and smart governance).

Hollands (2008) argued that smart cities are based on the utilization of networks to promote economic and political efficiency and to allow social, cultural and urban development. Caragliu et al. (2011) proposed that for a city to become smart, it must invest in human and social capital, traditional and modern information and communication technologies (ICT) and communication infrastructure, and must fuel sustainable economic growth and a high quality of life, with careful management of natural resources through participatory governance.

According to Carvalho (2017), a smart city is a smart regional ecosystem that includes various interconnected stakeholders that develop collaborative networks (firms, citizens, public organizations, cultural, economic and social infrastructures) to create an open and creative environment which is useful for improving the population's quality of life and for developing smart and innovative businesses and social projects. These regions present high standards regarding indicators associated with innovation, creativity, environment, quality of life, entrepreneurial activities and support facilities.

In general, the eclectic smart city concept includes not only infrastructures but also human and social factors (Aguilera et al., 2013). Nevertheless, as stated above, there is no consensual definition for this concept (Al Nuaimi et al., 2015) and the literature in general explores dimensions that influence cities' characteristics, as can be seen in Table 1.

Table 1. Smart cities dimensions

\begin{tabular}{|c|c|}
\hline Dimension & Authors \\
\hline ICT (use and availability) & $\begin{array}{l}\text { Bakici et al., 2013; Caragliu et al., 2011; } \\
\text { Hollands, 2008; Komninos, 2002; Thite, 2011; } \\
\text { Tranos and Gertner, } 2012 .\end{array}$ \\
\hline $\begin{array}{l}\text { Entrepreneurial ecosystems (entrepreneurial } \\
\text { activities and business creation) }\end{array}$ & $\begin{array}{l}\text { Carvalho, 2016; Gottdiener, 2001; Klein, 2000; } \\
\text { Monbiot, 2000; Hollands, 2008; Lombardi et al., } \\
\text { 2012; Thite, 2011; Lucas et al, } 2017 \text {. }\end{array}$ \\
\hline E-government and resident inclusion & $\begin{array}{l}\text { Bakici et al., 2013; Caragliu et al., 2011; } \\
\text { Hollands, 2008; Schaffers et al., 2011; Bernardo, } \\
2017 .\end{array}$ \\
\hline Creative industries and high tech & Hollands, 2008; Florida, 2002; Winters, 2011 \\
\hline Human capital and community & $\begin{array}{l}\text { Bolisani and Scarso, 2000; Kourtit et al., 2012; } \\
\text { Albuquerque, } 2017 .\end{array}$ \\
\hline Social capital and relationships & Coe et al., 2001; Kourtit et al., 2012. \\
\hline Social and environmental sustainability & $\begin{array}{l}\text { Caragliu et al., 2011; Nathan, 2013; Sen et al., } \\
\text { 2012; Shafiullah et al., 2013; Sivaram et al., } \\
\text { 2013.; Strielkowski, } 2017\end{array}$ \\
\hline
\end{tabular}

Source: Carvalho, 2017, adapted

Previous literature has explored dimensions that affect the characteristics of smart cities: the economy, human capital, technology, the environment, international outreach, social cohesion, mobility and transportation, governance, urban planning and public management (Berrone \& Ricart, 2017). However, it must be said that the determinants of the status quo of smart cities have been analysed to a lesser extent. In this sense, one of the approaches which is most often employed is to determine the factors that could also affect the development of smart cities. 


\subsection{Regional development and geography of smart cities}

The use of the term smart is connected to city and regional development (Dierwechter, 2017). In fact, smart growth is associated with a regional dimension. According to Dierwechter et al. (2017), "municipal borders should not hamper the search for sustainable development. Rather, regional cooperation between large cities and their suburbs and smaller towns, especially around curbing suburban sprawl, promoting public transport alternatives, and facilitating quality urban infill and creative densification, requires effective joint thinking and new forms of decision-making and civic trust". This perspective suggests that political and planning decisions are made at the regional scale (or city-regional level), raising the key question of governance. Governance implies collaboration, negotiation and deliberation among multiple actors, seeking to find mutually beneficial answers to complex problems (Herrschel \& Dierwechter, 2015; Hudalah, Zulfahmi \& Firman, 2013).

The study of smart cities assumes a regional dimension that justifies the application of empirical studies in a delimited geographic space, such as Europe. And why should smart cities in Europe be studied? According to the European Parliament (2014) in 2011, 240 of the 468 EU-28 cities with at least 100,000 inhabitants (51\% of the total) had at least one smart city characteristic and can therefore be classed as smart cities. The highest absolute number of smart cities is found in the UK, Spain and Italy; the countries with the highest proportion of smart cities are Italy, Austria, Denmark, Norway, Sweden, Estonia and Slovenia. Most smart city initiatives are still in the early phases of development, but larger cities tend to be the most mature (with at least one fully launched or implemented initiative). Based on the arguments outlined above, we test the following hypothesis:

H1: There is a significant relationship between the smart level of cities and the region to which they belong.

\subsection{Leadership and gender of smart cities}

The literature highlights the importance of governance in the achievement of the requisites for becoming a smart city. According to Mosher (1982), organizations will be more responsive to the public if they reflect the demographic characteristics of those they serve. Management literature on gender suggests some differences between the styles of women and men (Duflo, 2012).

Recent regulations echo the concern that discrimination may exist in access to boards, leading to inefficient use of the talent pool. Thus, they recommend increasing the number of female directors on governance boards. Several of these legislations explicitly argue that gender diversity improves the effectiveness of the council. However, emerging literature questions the view that female directors behave differently from their male colleagues (see, for example, Adams and Funk, 2012) and calls for research on the role of women in governance.

Previous literature suggests that male and female local councillors agree that women are more responsive to their constituencies (Beck, 2001); female mayors encourage citizens' participation, communication, and input more than men in that position (Fox \& Schuhmann, 1999). The increase in numbers of women in formal political representation, as council members or as mayors in municipalities, has influenced the structure of power and the functioning of municipalities in Spain (Araujo \& Tejedo-Romero, 2017). Nevertheless, studies on leadership and gender in municipalities of smart cities still are in their infancy. Based on the arguments outlined above, we test the following hypothesis: 
H2: There is a significant relationship between the smart level of cities and the gender of the person governing.

\subsection{Political ideologies and smart cities}

Previous literature claims that certain political ideologies are more favourable to influencing sustainable policies and consequently the development of smart cities (Steurer \& Hametrer, 2010; García-Sánchez \& Prado-Lorenzo, 2008; Nam \& Pardo, 2011). Nam and Pardo (2011) underline the key components of a smart city, which are technology, people (creativity, diversity, and education), and institutions (governance and policy). Connections exist between these latter two components and smart cities, so that a city is really smart when investments in human and social capital, together with information and communications technology (ICT) infrastructures, fuel sustainable growth and enhance the quality of life. The point of view of this study is that the smart city must provide some sort of interoperable and Internet-based government services that enable ubiquitous connectivity and transform key government processes towards citizens and businesses.

Public choice theory, developed by Mueller $(1979,1989)$, states that a complex political environment in which voters, interest groups and politicians play an important role in government decisions to adopt particular policies in general influences certain plans in the development of smart cities, in particular. Politicians play the role of agents appointed through an electoral process and always act in order to maximize the number of votes they expect to receive in the next election. According to Bavetta and Padocano (2000), politicians select an amount of resources and agents' time to provide policies to voters in exchange for votes, and to interest groups in exchange for resources, insofar as these can be reinvested to affect electoral outcomes.

Batty et al. (2012) point out that intelligent governance is an attribute that is associated with the governmental management of a city only when the city promotes itself as intelligent. Alkandari et al. (2012) indicate that the government should approve the development of the smart city and prioritize some areas, and Winters (2011) argues that urban governments should only promote higher education centres in order to develop smart cities. Finally, Nam and Pardo (2011) emphasize that smart governance is about promoting smart city initiatives.

Moreover, Smith and Fridkin (2008) argue that interparty competition plays a key role in the decision of politicians to devolve institutional power to citizens to a greater or lesser extent so that they have to pay attention to the demands of their constituents. Good governance and good policies can result in strong interactions at the urban level, while focusing on smart collaboration can result in more attention to collaboration issues than actually making things work. The question of what political ideology (for example, conservative or progressive parties) is more effective and more legitimate is an current issue. Anderson and Mizak (2006) relate that the main predictor of a vote for pro-environmental law is whether the American legislator is a liberal (left-wing) Democrat. In this sense, in Spain, Prado-Lorenzo et al. (2011) show that political competition improves cities' sustainability, while a leftist ideology has an inverse impact. Based on the arguments outlined above, we test the following hypothesis:

\section{H3: There is a significant relationship between the smart level of cities and the political} ideology of the rulers. 


\section{Methodological approach}

\subsection{Sample and data}

The selected population consists of 73 European cities whose smart city levels for the year 2017 were studied and classified by the IESE Business School; this is one of the most important business schools in the world and has been publishing an index of cities in recent years. Objective, exhaustive, broad and guided by the criteria of conceptual relevance and statistical rigour, the 2017 edition of the CIMI includes 180 cities, 73 of them capitals, representing 80 countries. The breadth of the project establishes the CIMI as one of the city indexes with the widest geographical coverage available at present. In addition, to calculate the index, the authors included 79 indicators that provide a complete overview of each city. Frameworks such as the Smart Cities Wheel (Cohen, 2017) and the European Smart Cities Ranking (Giffinger et al., 2007) have been developed to enable the comparison of cities and to assess cities' development in the desired direction. Other smart city performance assessment systems have been presented, for example by Albino et al. (2015), Lazaroiu and Roscia (2012), and Ahvenniemi, Huovila, Pinto-Seppä, and Airaksinen (2017).

The CIMI has empirically validated the conceptual model developed from 79 indicators that provide a complete vision of each city, grouped into $10 \mathrm{key}$ dimensions to determine efficiency: economy, human capital, technology, environment, international impact, social cohesion, mobility and transport, governance, urban planning and public management. All the indicators are linked to a strategic objective that leads to a new form of local economic development: the creation of a global city and the promotion of entrepreneurial spirit and innovation, among others. In Annex I, the scores of the cities included in the ranking and their positions are listed according to the 10 dimensions evaluated.

\subsection{Method}

The objective of this study is to analyse the factors that influence the development of sustainable smart cities. More specifically, in the first place we intend to identify possible similarities or differences between the cities of the sample in terms of their results as smart cities in relation to the ten dimensions established by the CIMI. For this purpose, a cluster analysis used in numerous studies, such as Mar and Serrano (2001), Pérez (2001), Pardo and Ruíz (2005), Navarro, Alcaraz and Ortiz (2010) and Nevado and Gallardo (2016), among others, was applied, was applied with variables to segment the positions of each of the ten dimensions. A hierarchical cluster was considered the best method to determine the optimum number of clusters in the data (Vilá, Hurtado, Berlanga and Fonseca, 2014).

Subsequently, in order to contrast the possible association or independence between the proposed factors (region, gender and political ideology) and the smart city levels resulting from the cluster analysis, contingency tables are used, due to the nature of the variables to contrast in our case, qualitative. All estimates are made using SPSS software, version 20.

\section{Conducting research and results}

Once the cluster analysis had been applied, in order to classify the cities according to the similarities and differences with respect to their smart city levels, three conglomerates were identified, which we called "High Level", "Medium Level" and "Low Level". Later, in order to verify that there are significant differences between the clusters obtained, an analysis of variance (ANOVA) was carried out. Table 2 demonstrates that the probabilities associated with 
the "F" statistic are zero for the ten dimensions, so we can confirm that there are statistically significant differences between the groups.

Table 2. Analysis of variance

\begin{tabular}{lccccc}
\hline & Sum of squares & gl & Quadratic media & F & Sig. \\
\hline Economy & 51279.355 & 2 & 25639.677 & 34.336 & 0.000 \\
\hline Human capital & 2672.431 & 2 & 13360.215 & 12.774 & 0.000 \\
\hline Social cohesion & 68081.381 & 2 & 34040.691 & 34.971 & 0.000 \\
\hline Environment & 33098.114 & 2 & 16549.057 & 21.573 & 0.000 \\
\hline Public management & 60153.908 & 2 & 30076.954 & 31.105 & 0.000 \\
\hline Governance & 76080.241 & 2 & 38040.121 & 42.925 & 0.000 \\
\hline Urban planning & 60203.071 & 2 & 30101.536 & 42.648 & 0.000 \\
\hline International impact & 65983.561 & 2 & 32991.780 & 24.074 & 0.000 \\
\hline Technology & 50138.104 & 2 & 25069.052 & 25.813 & 0.000 \\
\hline Mobility and transportation & 52318.160 & 2 & 26159.080 & 17.120 & 0.000 \\
\hline
\end{tabular}

Source: own compilation

In Annex II, the cities grouped in the different clusters obtained are presented. Graph 1 shows the behaviour of the clusters in relation to the average of the positions of the 10 dimensions. As can be seen, the cluster called "High Level" includes those cities that stand out favourably for reaching the best positions in the ranking. At the other extreme is the "Low Level" cluster, which includes those cities that obtained the least favourable positions in the ranking. The rest of the cities constitute the "Medium Level" cluster with intermediate positions.

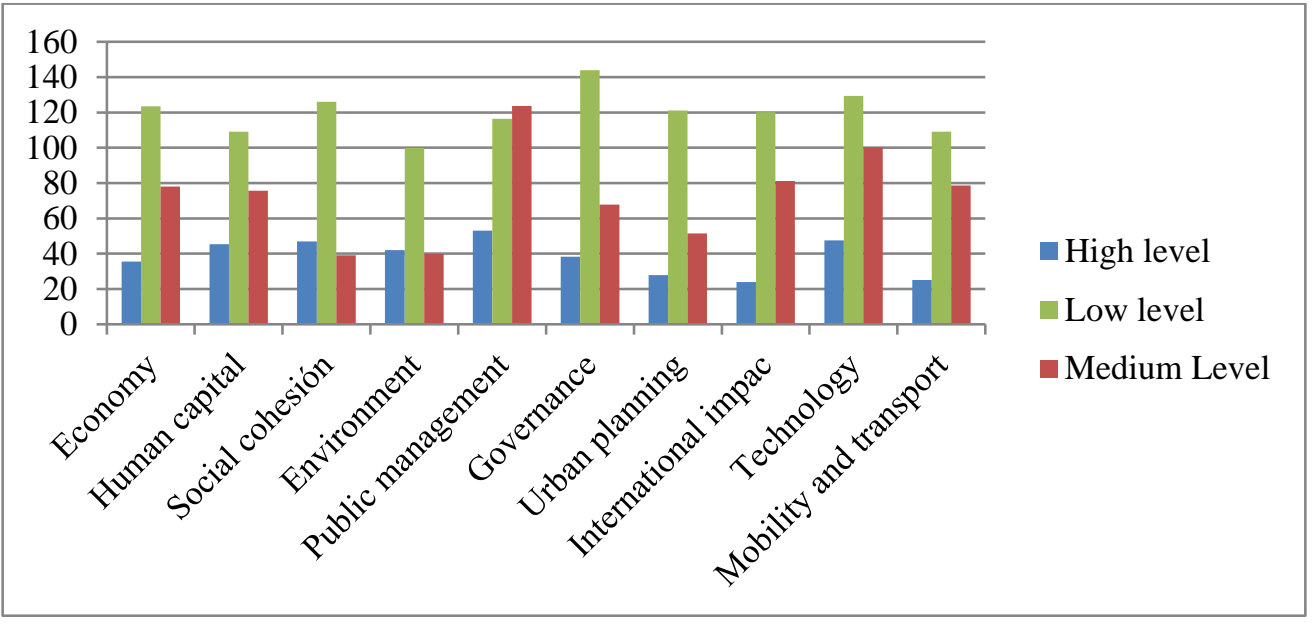

Graph 1. Distribution of means of the total ranking of smart cities (hierarchical procedure)

Source: own data

Secondly, once the clusters were formed, we proceeded to the analysis of the possible factors that affect the different levels of smart cities. Table 3 demonstrates the results of our analysis to test the first hypothesis of our study. In the first place, regarding the variable "geographic location" (Table 3), it can be observed that $21.9 \%$ of European cities have the highest smart city levels. All these cities belong to the western region. The average levels account for $63 \%$ of the cities in our sample, with the highest percentage $(68.6 \%)$ for the cities in the western region. Finally, $15.1 \%$ of European cities obtain the lowest smart city levels, all concentrated in the eastern region. A priori, a relationship can be seen between the variables. To verify this relationship, Pearson's chi-squared statistic was calculated, which yields a value 
of 33.24 with an associated probability of 0.000 , less than 0.01 . We can affirm, therefore, with a level of confidence of $99 \%$, that there is a significant relationship between smart city levels and the region to which the European cities belong, thus confirming hypothesis $H 1$. These results are consistent with the literature since, as mentioned above, it identifies Western Europe as being more prosperous and more industrialized than Eastern.

Table 3. Contingency Tables Smart City Levels * Region

\begin{tabular}{|c|c|c|c|c|c|}
\hline & & & \multicolumn{2}{|c|}{ Region } & \multirow{2}{*}{ Total } \\
\hline & & & West & East & \\
\hline \multirow{6}{*}{ Smart City Level } & \multirow{2}{*}{ High } & Count & 16 & 0 & 16 \\
\hline & & $\%$ by region & $31.4 \%$ & $0.0 \%$ & $21.9 \%$ \\
\hline & \multirow{2}{*}{ Medium } & Count & 35 & 11 & 46 \\
\hline & & $\%$ by region & $68.6 \%$ & $50.0 \%$ & $63.0 \%$ \\
\hline & \multirow{2}{*}{ Low } & Count & 0 & 11 & 11 \\
\hline & & $\%$ by region & $0.0 \%$ & $50.0 \%$ & $15.1 \%$ \\
\hline \multirow{2}{*}{ Total } & & Count & 51 & 22 & 73 \\
\hline & & $\%$ by region & $100.0 \%$ & $100.0 \%$ & $100.0 \%$ \\
\hline
\end{tabular}

Source: own compilation

Table 4 demonstrates the results of our analysis to test the second hypothesis of our study. For the variable "gender", the results reveal higher percentages of cities governed by women ( $28.6 \%$ compared to $19.2 \%$ of those governed by men) in the European cities that obtain the highest smart city levels. The same occurs with the cities that obtain average levels $(71.4 \%$ of cities governed by women as opposed to $59.6 \%$ of those governed by men). On the other hand, all cities that obtain the lowest levels of smart cities are governed by men. Given the value of chi-squared (0.369) and its associated probability (0.068), we can say with $90 \%$ confidence level that the gender variable is related to smart city levels in European cities, so hypothesis $H 2$ should not be rejected. Although the literature suggests some differences between men and women in governance, studies on leadership and gender in smart cities are still in their early stages. That is why this study provides relevant and novel information on one of the factors that favour the development of smart cities: the gender of the governor.

Table 4. Smart city Contingency levels' * Gender

\begin{tabular}{|c|c|c|c|c|c|}
\hline & & & \multicolumn{2}{|c|}{ Gender } & \multirow[t]{2}{*}{ Total } \\
\hline & & & Man & Woman & \\
\hline \multirow{6}{*}{ Level of the Smart Cities } & \multirow{2}{*}{ High } & Count & 10 & 6 & 16 \\
\hline & & $\%$ by gender & $19.2 \%$ & $28.6 \%$ & $21.9 \%$ \\
\hline & \multirow{2}{*}{ Medium } & Count & 31 & 15 & 46 \\
\hline & & $\%$ by gender & $59.6 \%$ & $71.4 \%$ & $63.0 \%$ \\
\hline & \multirow{2}{*}{ Low } & Count & 11 & 0 & 11 \\
\hline & & $\%$ by gender & $21.2 \%$ & $0.0 \%$ & $15.1 \%$ \\
\hline \multirow{2}{*}{\multicolumn{2}{|c|}{ Total }} & Count & Count & 21 & 73 \\
\hline & & $\%$ by gender & $\%$ by gender & $100.0 \%$ & $100.0 \%$ \\
\hline
\end{tabular}

Source: own compilation

Finally, Table 5 demonstrates the results of our analysis to test the third hypothesis of our study. Regarding the variable "political ideology", no significant differences are observed between the cities governed by conservative or progressive parties, so this variable does not 
seem to be significant for our model and sample. The calculated statistic (chi-squared $=0.077$ ) and its associated probability (0.962) indicate that the contrasted variable is not associated with smart city levels, which leads us to reject the proposed hypothesis $H 3$. However, these results are contradictory to the works of other authors such as Prado-Lorenzo et al. (2011) and Anderson and Mizak (2006), who obtained evidence that the political ideology of the governing parties affected the sustainability of cities. Specifically, they concluded that a leftist ideology negatively affects the development of cities.

Table 5. Contingency Smart Cities levels * Political ideology

\begin{tabular}{|c|c|c|c|c|c|c|}
\hline & & & \multicolumn{3}{|c|}{ Political ideology } & \multirow{2}{*}{ Total } \\
\hline & & & $\overline{\text { Conservative Pr }}$ & essive/Lib & lependent & \\
\hline \multirow{6}{*}{$\begin{array}{l}\text { Smart City } \\
\text { Level }\end{array}$} & \multirow[b]{2}{*}{ High } & Count & 8 & 8 & 0 & 16 \\
\hline & & $\begin{array}{c}\% \text { by political } \\
\text { ideology }\end{array}$ & $22.9 \%$ & $23.5 \%$ & $0.0 \%$ & $21.9 \%$ \\
\hline & \multirow[b]{2}{*}{ Medium } & Count & 23 & 21 & 2 & 46 \\
\hline & & $\begin{array}{c}\% \text { by political } \\
\text { ideology }\end{array}$ & $65.7 \%$ & $61.8 \%$ & $50.0 \%$ & $63.0 \%$ \\
\hline & \multirow[b]{2}{*}{ Low } & Count & 4 & 5 & 2 & 11 \\
\hline & & $\begin{array}{c}\% \text { by political } \\
\text { ideology }\end{array}$ & $11.4 \%$ & $14.7 \%$ & $50.0 \%$ & $15.1 \%$ \\
\hline \multirow{2}{*}{\multicolumn{2}{|c|}{ Total }} & Count & Count & 34 & 4 & 73 \\
\hline & & $\begin{array}{c}\% \text { by political } \\
\text { ideology }\end{array}$ & $\begin{array}{c}\% \text { by political } \\
\text { ideology }\end{array}$ & $100.0 \%$ & $100.0 \%$ & $100.0 \%$ \\
\hline
\end{tabular}

Source: own compilation

\section{Conclusion}

This work allowed us to obtain empirical evidence and contribute to the generation of knowledge about smart cities, which is important given the lack of research with this orientation so far. Thus an existing void in the academic literature is filled, since the analysis of the factors that influence the development of smart cities is at a relatively early stage of development and the study of it is considered as necessary and of interest.

To do this, based on the values of the CIMI developed by IESE Business School, the similarities and differences between 73 European cities were analysed in terms of their economy, human capital, technology, environment, international impact, social cohesion, mobility and transport, governance, urban planning and public management, obtaining three clearly differentiated groups: a first group of cities that obtain the highest smart city levels, a second group of cities with medium levels and a third group that present the lowest levels.

Regarding the analysis of the associated factors, evidence was found showing that smart city levels are related to the geographical location of the cities and the gender of the governors. However, it was not possible to ascertain any type of association with the political ideology of the governing team. We can conclude, therefore, that those cities located in the western region obtain better results as smart cities. The same applies to cities governed by women, which achieve the best results in the smart cities ranking. Finally, whether the representatives of the government of the cities have conservative or progressive ideologies does not seem to be determinant for the cities to reach high positions in the ranking.

Smart cities have raised many questions which remain unsolved at the moment. One key question is the role of governments in these cities (Rodríguez-Bolívar, 2015). Prior research has no definitive conclusions about these questions. In fact, experiences around the world seem 
to indicate that each smart city has been developed according to its own characteristics and environment. So what are the developmental factors for becoming smart? Do governments have to be forced to follow guidelines to achieve these goals? Previous research has indicated that the transformation process will only be achieved with better governance and its particular features such as leadership, gender and political ideologies (Araujo \& Tejedo-Romero, 2017; Prado-Lorenzo et al., 2011). The idea of intelligent city governance fits well in the public management perspective, which highlights that the solution of social problems is not only a matter of developing good policies, but is much more a managerial issue of organizing strong collaborations between government and other stakeholders (Torfing et al., 2012). In fact, it is important to explore the factors based on smart and sustainable urban initiatives in the long term.

In addition, the environment is a key factor for smart cities. Thus, the regional and transnational location of cities is a relevant factor for the construction of dense and diversified relations of economic networks. It is also important to note that government administrations are key actors in the governance process. These should stimulate investment and focus on the development and implementation of policies that foster smart and sustainable development.

Finally, this study suggests some clues for future research, such as analysis of the reasons and motivations that may lead cities to obtain high smart city levels and studies on governance and influence of the leadership in local administration.

\section{Funding}

This work was supported by Institute Polytechnic of Setúbal (School of Business and Administration) and Foundation for Science and Technology, grants: UIDB / 00315/2020 and UIDB/04007/2020.

\section{References}

Abdala, L. N., Schreiner, T., da Costa, E. M., \& dos Santos, N. (2014). Como as cidades inteligentes contribuem para o desenvolvimento de cidades sustentáveis?: Uma revisão sistemática de literatura. International Journal of Knowledge Engineering and Management (IJKEM), 3(5), 98-120.

Albuquerque, C. (2017). Cities really smart and inclusive: Possibilities and limits for social inclusion and participation in Luísa Carvalho (ed.), Handbook of Research On Entrepreneurial Development and Innovation within Smart Cities, Pennsylvania, USA: IGI Global, 239-258 (ISBN-13: 978-1522519782).

Adams, R.B., \& P. Funk (2012). Beyond the glass ceiling: does gender matter?. Management Science, 58, 219-235.

Ahvenniemi, H., Huovila, A., Pinto-Seppä, I., \& Airaksinen, M. (2017). What are the differences between sustainable \& smart cities?. Cities, 60, 234-245. https://doi.org/10.1016/j.cities.2016.09.009.

Aguilera, G., Galán, J.L., Campos, J.C., \& Rodríguez, P. (2013). An accelerated-time simulation for traffic flow in a smart city. FEMTEC, 26.

Al Nuaimi, E., Al Neyadi, H., Mohamed, N., \& Al-Jarrodi, J. (2015). Applications of big data to smart cities. Journal of Internet Services and Applications, 6-25.

Alkandari A, Alnasheet, M., \& Alshekhly, IFT. (2012) Smart cities: Survey. Journal of Advanced Computer Science and Technology Research, 2(2), 79-90.

Anderson, W., \& Mizak, D. (2006). Politics of environmental law: Political ideology, elitism or urban-rural interests?. Public Choice, 1(29), 131-157. 
Araujo, J., \& Tejedo-Romero, F. (2017). Does gender equality affect municipal transparency: The case of Spain. Public Performance \& Management Review, 1-31.

Bakıc1, T., Almirall, E. \& Wareham, J. (2013). A smart city initiative: the case of Barcelona. Journal of the Knowledge Economy, 4(2), 135-148.

Bavetta, S., \& Padovano, F. (2000). A model of the representation of interest in a compound democracy. Constit. Polit. Econ., 11(1), 5-25.

Beck, S. A. (2001). Acting as women: The effects and limitations of gender in local governance. In S. J. Carroll (Ed.), The impact of women in public office. Bloomington, IN: Indiana University Press (49-67). Available at: https://muse.jhu.edu/chapter/234772.

Bernardo, M. R. (2017). Smart city governance: from e-government to smart governance. In Luísa Carvalho (ed.), Handbook of Research On Entrepreneurial Development and Innovation within Smart Cities, Pennsylvania, USA: IGI Global, 300-336 (ISBN-13: 9781522519782).

Berrone, \& Ricart. (2017). IESE Cities in Motion, Business School, University of Navarra. Available at: http://www.iese.edu/research/pdfs/ST-0396-E.pdf

Brkljačić, T., Majetić, F., \& Tarabić, B. (2017) Smart Environment: Cyber Parks. In Luísa Carvalho (ed.), Handbook of Research On Entrepreneurial Development and Innovation within Smart Cities, Pennsylvania, USA: IGI Global, 160-181 (ISBN-13: 9781522519782).

Caragliu, A., Del Bo, C., \& Nijkamp, P. (2011). Smart cities in Europe. Journal of Urban Technology, 18(2), 65-82.

Carvalho, L. (2017). Entrepreneurial Ecosystems. Lisbon as a Smart Start-up City. In Luísa Carvalho (ed.), Handbook of Research on Entrepreneurial Development and Innovation within Smart Cities, Pennsylvania, USA: IGI Global, 1-24 (ISBN-13: 978-1522519782).

Cohen, B. (2017). Retrieved from http: //www.boydcohen.com/smartcities.html (accessed 20.2.2017)

Dierwechter, Y. (2017). Urban Sustainability through Smart Growth: Intercurrence, Planning, and Geographies of Regional Development across Greater Seattle. Cham: Springer.

Dierwechter, Y., Herrschel, T., \& Lintz, G. (2017). Smart city-regional governance for sustainability? Reflections Issue 20, University of Westminster, Regional Studies Research Network on Smart City-Regional Governance for Sustainability.

Duflo, E. (2012). Women empowerment and economic development. Journal of Economic Literature, 50(4), 1051-1079. doi:10.1257/jel.50.4.1051.

European Union. (2014). Smart cities and sustainable development. Available at: https://eusmartcities.eu/sites/all/files/blog/files/EIB\%20\%26\%20EIP\%20Smart\%20Cities\%20Fin ancing_0.pdf

European Parliament. (2014). Mapping Smart Cities in the EU. Directorate General for Internal Policies. Policy Department. Available at: http://www.europarl.europa.eu/RegData/etudes/etudes/join/2014/507480/IPOLITRE_ET(2014)507480_EN.pdf

Fox, R. L., \& Schuhmann, R. A. (1999). Gender and local government: A comparison of women and men city managers. Public Administration Review, 59(3), 231-242.

García-Sánchez, I.M., \& Prado-Lorenzo, J.M. (2008). Determinant factors in the degree of implementation of Local Agenda 21 in the European Union. Sustainability Development, 16,17 - 34.

Giffinger, R., Fertner, C., Kramar, H., Kalasek, R., Pichler-Milanovic, M., \& Meijers, E. (2007). Smart cities: ranking of European medium-sized cities. Available at: http://smartcity-ranking.org/download/smart_cities_final_report.pdf 
Hall, R.E. (2000). The vision of a smart city. In Proceedings of the 2nd International Life Extension Technology Workshop, Paris, France, 28 September.

Herrschel, T., \& Dierwechter, Y. (2015). Smart city-regional governance: a dual transition. Regions, 300 (4), 20-21.

Hollands, R.G. (2008). Will the real Smart City please stand up?. City: Analysis of Urban Trends, Culture, Theory, Policy and Action, 13(3), 303-320.

Hudalah, D., Zulfahmi, F., \& Firman, T. (2013). Regional governance in decentralizing indonesia: learning from the success of urban-rural cooperation in metropolitan Yogyakarta. In T. Bunnell, D. Parthasarathy, y E. C. Thompson (Eds.), Cleavage, Connection and Conflict in Rural, Urban and Contemporary Asia (65-82): Springer Netherlands.

Karyy, O., \& Knjazevska, O. (2009). Tasks prioritization of strategic planning of cities development: experts' approach. Economics \& Sociology, 2(1), 58-66.

Komninos, N. (2002). Intelligent cities: innovation, knowledge systems, and digital spaces. London: Routledge, 2002.

Lee, J.H., Phaal, R., \& Lee, S.-H. (2013). An integrated service-device-technology roadmap for smart city development. Technological Forecasting \& Social Change, 80(2), 286-306.

Lazaroiu, G., \& Roscia, M. (2012). Definition methodology for the smart cities model. Energy, 47 (1), 326-332.

Lombardi, P., Giordano, S., Farouh, H., \& Yousef, W. (2012). Modelling the smart city performance. Innovation: The European Journal of Social Science Research 25(2), 137149.

Lucas, M.R., Rego, C., Vieira, C., \& Vieira, I. (2017). Proximity an cooperation for innovative regional development: The case of science and technology park. In Luísa Carvalho (ed.), Handbook of Research On Entrepreneurial Development and Innovation within Smart Cities, Pennsylvania, USA: IGI Global, 208-238 (ISBN-13: 978-1522519782).

Mar, M. C. \& Serrano, C. (2001). Bank failure: a multidimensional scaling approach. European Journal of Finance, 7(2), 165-183.

Mckinsey Global Institute. (2011). Urban world: mapping the economic power of cities. MGI.

Mosher, F. (1982). Democracy and the public service (2nd ed.). New York, NY: Oxford. University Press.

Mueller, D.C. (1979). Public Choice. University Press, Cambridge.

Mueller, D.C. (1989). Public Choice II. University Press, Cambridge.

Nam, T., \& T.A. Pardo, T.A. (2011). Conceptualizing Smart City with Dimensions of Technology, People, and Institutions, Proc. 12th Conference on Digital Government Research, College Park, MD, June 12-15.

Navarro, G. A., Alcaraz, F. J., \& Ortiz, D. (2010). La divulgación de información sobre responsabilidad corporativa en administraciones públicas: un estudio empírico en gobiernos locales. Revista Española de Contabilidad, RC-SAC, 13(2), 285-314.

Nevado-Gil, M. T. \& Gallardo-Vázquez, D. (2016). Información sobre Responsabilidad Social contenida en las páginas webs de los ayuntamientos. Estudio en la región del Alentejo. Revista española de Documentación Científica, 39(4), 150.

ONU (2012). Resilient people, resilient planet: a future worth choosing. Report of the United Nations secretary general's high-level panel on global sustainability.

Pardo Merino, A., \& Ruiz Diaz, M. A. (2005). Análisis de Datos con SSPS 13 Base. Aravaca: MCGraw-Hill.

Pérez, C. (2001). Técnicas estadísticas con SSPS. Madrid: Pearson Prentice Hall. 
Prado-Lorenzo, J., García-Sanchez, I., \& Cuadrado-Ballesteros, B. (2011). Sustainable cities: do political factors determine the quality of life?. Journal of Cleaner Production, 21, 3444.

Sánchez Carrión, J. J. (1989). Análisis de tablas de contingencia. Centro de Investigaciones Sociológicas, 105, 171.

Smith, D., \& Fridkin, D. (2008). Delegating direct democracy: interparty legislative competition and the adoption of the initiative in the American States. The American Political Science Review, 102(3), 333-350.

Steurer, R., \& Hametrer, M. (2010). Objectives and indicators in sustainable development strategies: similarities and variances across Europe. Sustainability Development. doi:10.1002/sd.501.

Strielkowski, W. (2017), Social and economic implications for the smart grids of the future. Economics and Sociology, 10(1), 310-318.

Thite, M. (2011). Smart cities: implications of urban planning for human resource development. Human Resource Development International, 14(5), 623-631.

Tranos, E., \& Gertner, D. (2012). Smart networked cities?. Innovation: The European Journal of Social Science Research, 25(2), 175-190.

UNEP (2011). Towards a green economy: Pathways to sustainable development and poverty eradication. UNEP.

Vilá, B.R., Hurtado, M. J. R., Berlanga, V. V., \& Fonseca, M. T. (2014). Com aplicar un clúster jeràrquic en SPSS. REIRE. Revista d'Innovació i Recerca en Educació, 7(1), 113-127.

Walravens, N. (2012). Mobile business and the smart city: Developing a business model framework to include public design parameters for mobile city services. Journal of Theoretical and Applied Electronic Commerce Research, 7(3), 121-135.

Washburn, D., Sindhu, U., Balaouras, S., Dines, R. A., Hayes, N. M., \& Nelson, L.E. (2010). Helping CIOs Understand "Smart City" Initiatives: Defining the Smart City, Its Drivers, and the Role of the CIO (Cambridge, MA: Forrester Research).

Winters, J.V. (2011). Why are smart cities growing? Who moves and who stays. Journal of Regional Science, 51(2), 253-270. 
Annex I. Cities in Motion Index (CIMI) Ranking

\begin{tabular}{|c|c|c|c|c|c|c|c|c|c|c|c|}
\hline \multirow[b]{2}{*}{ Ciudad } & \multirow[b]{2}{*}{ CIMI } & \multirow[b]{2}{*}{ Economy } & \multirow[b]{2}{*}{$\begin{array}{l}\text { Human } \\
\text { capital }\end{array}$} & \multirow[b]{2}{*}{$\begin{array}{c}\text { Social } \\
\text { cohesion }\end{array}$} & \multirow[b]{2}{*}{ Environment $_{\mathrm{I}}$} & \multirow[b]{2}{*}{$\begin{array}{c}\text { Public } \\
\text { management }\end{array}$} & \multirow[b]{2}{*}{ t Governance } & \multicolumn{3}{|c|}{ Position } & \multirow[b]{2}{*}{$\begin{array}{c}\text { Mobility and } \\
\text { transport }\end{array}$} \\
\hline & & & & & & & & $\begin{array}{c}\text { Urban } \\
\text { planning }\end{array}$ & $\begin{array}{l}\text { International } \\
\text { impact }\end{array}$ & Technology & \\
\hline London-United Kingdom & 98.71 & 4 & 1 & 105 & 35 & 34 & 23 & 22 & 2 & 23 & 1 \\
\hline Paris-France & 91.97 & 11 & 7 & 86 & 20 & 45 & 42 & 8 & 1 & 25 & 5 \\
\hline Berlin-Germany & 83.40 & 54 & 23 & 10 & 11 & 42 & 33 & 7 & 10 & 63 & 8 \\
\hline Amsterdam-Netherlands & 82.86 & 32 & 34 & 26 & 95 & 56 & 31 & 1 & 7 & 6 & 20 \\
\hline Zurich-Switzerland & 82.51 & 18 & 78 & 2 & 1 & 24 & 25 & 32 & 48 & 75 & 80 \\
\hline Vienna-Austria & 81.94 & 46 & 42 & 12 & 3 & 87 & 36 & 19 & 14 & 46 & 9 \\
\hline Sydney-Australia & 81.14 & 17 & 37 & 58 & 30 & 16 & 37 & 20 & 33 & 24 & 71 \\
\hline Geneva-Switzerland & 81.14 & 25 & 105 & 14 & 55 & 1 & 64 & 4 & 46 & 33 & 58 \\
\hline Munich-Germany & 80.71 & 35 & 33 & 8 & 18 & 61 & 32 & 11 & 34 & 34 & 10 \\
\hline Stockholm-Sweden & 77.76 & 24 & 75 & 54 & 4 & 81 & 30 & 66 & 37 & 55 & 7 \\
\hline Oslo-Norway & 77.75 & 20 & 20 & 21 & 22 & 96 & 77 & 3 & 58 & 72 & 18 \\
\hline Copenhagen-Denmark & 77.56 & 31 & 31 & 6 & 41 & 162 & 17 & 29 & 27 & 53 & 17 \\
\hline Madrid-Spain & 77.00 & 57 & 43 & 66 & 52 & 50 & 48 & 31 & 15 & 59 & 6 \\
\hline Helsinki-Finland & 76.91 & 42 & 62 & 1 & 29 & 117 & 10 & 33 & 63 & 52 & 28 \\
\hline Dublin-Ireland & 74.47 & 22 & 77 & 64 & 70 & 52 & 21 & 65 & 24 & 89 & 54 \\
\hline Hamburg-Germany & 74.20 & 47 & 36 & 18 & 47 & 70 & 27 & 23 & 79 & 85 & 24 \\
\hline Barcelona-Spain & 74.10 & 77 & 39 & 72 & 84 & 67 & 35 & 43 & 4 & 64 & 26 \\
\hline Frankfurt-Germany & 74.03 & 41 & 29 & 56 & 59 & 80 & 41 & 49 & 54 & 58 & 3 \\
\hline Milan-Italy & 73.66 & 56 & 35 & 71 & 46 & 69 & 79 & 14 & 23 & 61 & 15 \\
\hline Glasgow-United Kingdom & 73.18 & 53 & 40 & 16 & 57 & 91 & 18 & 52 & 93 & 48 & 59 \\
\hline Brussels-Belgium & 72.89 & 49 & 68 & 47 & 89 & 84 & 34 & 53 & 30 & 45 & 30 \\
\hline Prague-Czech Republic & 71.87 & 93 & 73 & 5 & 14 & 114 & 114 & 21 & 16 & 105 & 67 \\
\hline$\underline{\text { Rome-Italy }}$ & 71.64 & 78 & 41 & 115 & 36 & 60 & 89 & 16 & 9 & 60 & 65 \\
\hline Stuttgart-Germany & 70.83 & 45 & 70 & 3 & 33 & 119 & 59 & 28 & 124 & 110 & 52 \\
\hline Linz-Austria & 70.22 & 55 & 24 & 27 & 5 & 163 & 40 & 61 & 28 & 71 & 161 \\
\hline Basel-Switzerland & 70.13 & 34 & 101 & 4 & 68 & 37 & 62 & 57 & 119 & 146 & 53 \\
\hline Florence-Italy & 70.02 & 98 & 65 & 15 & 31 & 100 & 58 & 17 & 26 & 96 & 126 \\
\hline Lyon-France & 70.00 & 64 & 47 & 24 & 23 & 94 & 86 & 39 & 90 & 65 & 50 \\
\hline Málaga-Spain & 69.71 & 123 & 134 & 35 & 51 & 116 & 56 & 62 & 13 & 76 & 45 \\
\hline Lisbon-Portugal & 69.42 & 71 & 99 & 60 & 44 & 92 & 39 & 58 & 22 & 86 & 110 \\
\hline Tallinn-Estonia & 69.25 & 63 & 69 & 9 & 2 & 126 & 102 & 74 & 62 & 87 & 101 \\
\hline Warsaw-Poland & 68.96 & 95 & 59 & 29 & 16 & 142 & 93 & 6 & 83 & 70 & 41 \\
\hline $\begin{array}{l}\text { Liverpool-United } \\
\text { Kingdom } \\
\end{array}$ & 68.77 & 50 & 52 & 20 & 21 & 128 & 16 & 91 & 110 & 149 & 72 \\
\hline $\begin{array}{l}\text { Manchester-United } \\
\text { Kingdom }\end{array}$ & 68.59 & 52 & 25 & 37 & 73 & 63 & 22 & 76 & 103 & 100 & 125 \\
\hline Eindhoven-Netherlands & 68.55 & 62 & 94 & 36 & 81 & 156 & 38 & 18 & 87 & 31 & 109 \\
\hline Rotterdam-Netherlands & 68.26 & 60 & 61 & 30 & 71 & 120 & 53 & 9 & 111 & 93 & 106 \\
\hline Cologne-Germany & 67.81 & 59 & 57 & 48 & 67 & 138 & 66 & 56 & 53 & 112 & 27 \\
\hline Turin-Italy & 67.53 & 103 & 109 & 80 & 17 & 139 & 50 & 12 & 92 & 99 & 32 \\
\hline $\begin{array}{l}\text { Birmingham-United } \\
\text { Kingdom }\end{array}$ & 67.10 & 48 & 30 & 31 & 75 & 133 & 9 & 98 & 153 & 143 & 70 \\
\hline Valencia-Spain & 66.83 & 111 & 126 & 39 & 45 & 105 & 60 & 54 & 80 & 78 & 34 \\
\hline Antwerp-Belgium & 66.51 & 72 & 95 & 7 & 40 & 127 & 47 & 26 & 135 & 153 & 107 \\
\hline Budapest-Hungary & 65.93 & 105 & 45 & 73 & 72 & 158 & 81 & 48 & 32 & 92 & 25 \\
\hline Seville-Spain & 65.88 & 118 & 130 & 45 & 50 & 130 & 43 & 59 & 65 & 69 & 64 \\
\hline $\begin{array}{l}\text { Nottingham-United } \\
\text { Kingdom }\end{array}$ & 65.82 & 61 & 50 & 25 & 24 & 168 & 22 & 85 & 158 & 128 & 87 \\
\hline Ljubljana-Slovenia & 65.58 & 102 & 86 & 23 & 9 & 124 & 88 & 79 & 117 & 94 & 75 \\
\hline Vilnius-Lithuania & 65.44 & 83 & 64 & 38 & 7 & 135 & 105 & 72 & 99 & 106 & 88 \\
\hline Marseille-France & 65.27 & 73 & 63 & 83 & 54 & 111 & 82 & 42 & 106 & 97 & 47 \\
\hline Nice-France & 65.00 & 80 & 72 & 19 & 27 & 129 & 101 & 60 & 51 & 171 & 79 \\
\hline Bilbao-Spain & 65.00 & 99 & 88 & 52 & 49 & 153 & 45 & 77 & 75 & 145 & 35 \\
\hline Leeds-United Kingdom & 64.70 & 58 & 48 & 22 & 25 & 152 & 14 & 84 & 168 & 138 & 164 \\
\hline Bratislava-Slovakia & 64.61 & 74 & 79 & 13 & 66 & 118 & 130 & 40 & 101 & 88 & 120 \\
\hline A Coruña-Spain & 64.35 & 114 & 143 & 57 & 48 & 166 & 90 & 38 & 35 & 80 & 84 \\
\hline Lille-France & 64.10 & 88 & 80 & 50 & 56 & 146 & 75 & 68 & 67 & 133 & 69 \\
\hline Riga-Latvia & 63.67 & 65 & 74 & 33 & 26 & 99 & 111 & 120 & 78 & 126 & 78 \\
\hline Zagreb-Croatia & 63.22 & 121 & 100 & 51 & 6 & 150 & 84 & 92 & 107 & 111 & 94 \\
\hline Gothenburg-Sweden & 61.85 & 37 & 84 & 55 & 12 & 154 & 80 & 90 & 125 & 127 & 146 \\
\hline
\end{tabular}


RECENT ISSUES IN ECONOMIC DEVELOPMENT

\begin{tabular}{|c|c|c|c|c|c|c|c|c|c|c|c|}
\hline Sofia-Bulgaria & 61.57 & 144 & 66 & 69 & 13 & 90 & 135 & 71 & 118 & 101 & 105 \\
\hline Naples-Italy & 60.99 & 128 & 117 & 85 & 69 & 131 & 97 & 37 & 91 & 95 & 83 \\
\hline Athens-Greece & 60.90 & 115 & 67 & 160 & 99 & 95 & 95 & 25 & 39 & 98 & 46 \\
\hline Wrocław-Poland & 60.64 & 127 & 123 & 68 & 19 & 169 & 108 & 10 & 105 & 68 & 155 \\
\hline Duisburg-Germany & 59.85 & 76 & 133 & 43 & 63 & 147 & 92 & 80 & 104 & 142 & 132 \\
\hline Porto-Portugal & 59.10 & 91 & 151 & 17 & 32 & 151 & 133 & 73 & 55 & 161 & 145 \\
\hline Istanbul-Turkey & 57.39 & 92 & 136 & 152 & 134 & 68 & 159 & 87 & 6 & 54 & 124 \\
\hline Bucharest-Romania & 56.10 & 120 & 83 & 77 & 148 & 62 & 115 & 99 & 88 & 109 & 76 \\
\hline Kiev-Ukraine & 53.02 & 132 & 58 & 149 & 97 & 98 & 143 & 111 & 149 & 154 & 31 \\
\hline Belgrade-Serbia & 52.11 & 149 & 111 & 122 & 98 & 103 & 128 & 110 & 100 & 91 & 136 \\
\hline Tbilisi-Georgia & 51.89 & 117 & 120 & 106 & 61 & 132 & 131 & 109 & 142 & 136 & 166 \\
\hline Minsk-Belarus & 51.72 & 101 & 82 & 88 & 64 & 141 & 168 & 155 & 159 & 164 & 86 \\
\hline $\begin{array}{l}\text { Sarajevo-Bosnia- } \\
\text { Herzegovina }\end{array}$ & 49.88 & 179 & 106 & 148 & 74 & 171 & 125 & 112 & 126 & 130 & 62 \\
\hline Skopje-Macedonia & 47.21 & 116 & 168 & 151 & 43 & 112 & 142 & 117 & 140 & 162 & 176 \\
\hline Baku-Azerbaijan & 47.08 & 104 & 89 & 166 & 122 & 143 & 163 & 138 & 155 & 121 & 73 \\
\hline Ankara-Turkey & 46.76 & 119 & 131 & 136 & 142 & 78 & 154 & 137 & 144 & 134 & 140 \\
\hline Bursa-Turkey & 44.91 & 130 & 115 & 91 & 116 & 173 & 156 & 157 & 113 & 169 & 131 \\
\hline
\end{tabular}

Annex II. Cities included in the different clusters

\begin{tabular}{|c|c|c|c|}
\hline $\begin{array}{c}\text { High Level of Smart } \\
\text { City }\end{array}$ & \multicolumn{2}{|c|}{ Medium Level of Smart City } & \multirow{2}{*}{$\begin{array}{c}\text { Low Level of Smart City } \\
\text { Istanbul-Turkey }\end{array}$} \\
\hline London-United & Oslo-Norway & Kingdom & \\
\hline Kingdom & Copenhagen-Denmark & Valencia-Spain & Bucharest-Romania \\
\hline Paris-France & Helsinki-Finland & Antwerp-Belgium & Kiev-Ukraine \\
\hline Berlin-Germany & Hamburg-Germany & Budapest-Hungary & Belgrade-Serbia \\
\hline Amsterdam- & Glasgow-United & Seville-Spain & Tbilisi-Georgia \\
\hline Netherlands & Kingdom & Nottingham-United & Minsk-Belarus \\
\hline Zurich-Switzerland & Prague-Czech Republic & Kingdom & Sarajevo-Bosnia- \\
\hline Vienna-Austria & Rome-Italy & Ljubljana-Slovenia & Herzegovina \\
\hline Sydney-Australia & Stuttgart-Germany & Vilnius-Lithuania & Skopje-Macedonia \\
\hline Geneva-Switzerland & Linz-Austria & Marseille-France & Baku-Azerbaijan \\
\hline Munich-Germany & Basel-Switzerland & Nice-France & Ankara-Turkey \\
\hline Stockholm-Sweden & Florence-Italy & Bilbao-Spain & Bursa-Turkey \\
\hline Madrid-Spain & Lyon-France & Leeds-United Kingdom & \\
\hline Dublin-Ireland & Málaga-Spain & Bratislava-Slovakia & \\
\hline Barcelona-Spain & Lisbon-Portugal & A Coruña-Spain & \\
\hline Frankfurt-Germany & Tallinn-Estonia & Lille-France & \\
\hline Milan-Italy & Warsaw-Poland & Riga-Latvia & \\
\hline \multirow[t]{9}{*}{ Brussels-Belgium } & Liverpool-United & Zagreb-Croatia & \\
\hline & Kingdom & Gothenburg-Sweden & \\
\hline & Manchester-United & Sofia-Bulgaria & \\
\hline & Kingdom & Naples-Italy & \\
\hline & Eindhoven-Netherlands & Athens-Greece & \\
\hline & Rotterdam-Netherlands & Wrocław-Poland & \\
\hline & Cologne-Germany & Duisburg-Germany & \\
\hline & Turin-Italy & Porto-Portugal & \\
\hline & Birmingham-United & & \\
\hline
\end{tabular}

